Civil Engineering Specification 
By the same author

Civil Engineering Quantities

Building Quantities Explained

Municipal Engineering Practice 


\title{
Civil \\ Engineering Specification
}

\author{
Ivor H. SEeley \\ B.Sc., M.A., C.Eng., M.I.Mun.E., F.R.I.C.S., F.I.Q.S. \\ Chartered Engineer and Surveyor
}

Macmillan Education 
(C) Ivor H. Seeley 1968

Softcover reprint of the hardcover 1st edition 1968

ISBN 978-1-349-00283-2 ISBN 978-1-349-00281-8 (eBook)

DOI 10.1007/978-1-349-00281-8

Published by

MACMILLAN \& CO LTD

Little Essex Street London WC2

and also at Bombay Calcutta and Madras

Macmillan South Africa (Publishers) Pty Ltd Johannesburg

The Macmillan Company of Australia Pty Ltd Melbourne

The Macmillan Company of Canada Ltd Toronto

St Martin's Press Inc New York

First published 1968

$9^{\prime \prime} \times 6^{\prime \prime}$ trimmed, viii $+245 \mathrm{pp}$.

1 line illustration 


\section{Preface}

THIS book is primarily concerned with the drafting of specification clauses for civil and municipal engineering work. The specification on a civil engineering contract constitutes a contract document and its provision is essential if the material and workmanship requirements of the job are to be adequately detailed.

The book sets out to indicate how a comprehensive and yet straightforward specification can be produced. The specification acts as one of the principal lines of communication between the Engineer and the Contractor and thus requires the exercise of considerable care and skill in its preparation.

The contents of this book should be helpful to engineers when compiling specifications and also of value to students who are studying the subject for degrees, diplomas and professional examinations in civil and municipal engineering.

Units of measurement, weight and pressure have been converted to their nearest metric equivalents using the analogue or 'rounding-off' method, and the imperial units are shown in brackets. Appendix IV contains an anologue metric conversion table which readers may find useful when preparing their own specifications on the metric system.

At the time of going to press the final decision on the form of the decimal marker had not been made by all participant bodies, but the point has been used throughout in line with the recommendation of the Decimal Currency Board.

Nottingham,

I. H. SeEley

Spring 1968 


\section{ACKNOWLEDGEMENTS}

THE author expresses his indebtedness to the various consulting and municipal engineers from whom over the years he has received valuable experience and guidance in the drafting of specifications.

Grateful thanks are also due to P. J. Edmonds Esq. and T. E. Blackall Esq. of the publishers for abundant help and consideration during the production of the book. 


\section{Contents}

Preface v

Acknowledgements vi vi

1 Civil Engineering Contracts 1

Contract Documents: Form of Contract; General Conditions of Contract;

Specification; Bill of Quantities; Contract Drawings; Form of Tender -

I.C.E. Conditions - I.Struct.E. Conditions - Types of Contract.

2 Purpose AND ARRANGement of ANd Sources of INFORMATION FOR SPECIFICATIONS

Functions of Specification - General Arrangement - Drafting of Specification Clauses - Sources of Information - British Standards Codes of Practice.

3 General Clauses in Specifications

General Contractual Matters - Legal Provisions - General Matters affecting Cost of Job - Use of Site - Temporary Works - Materials and Workmanship Requirements - General Working Requirements - Records.

4 SPECIFICATION OF EARTHWORK

Site Investigation and Clearance - Excavation, Fill and Disposal Keeping Excavations free from Water - Timbering - Tunnel Work Cofferdams - Dredging.

\section{SPeCification of CONCRETE Work}

Materials - Concrete Work, including mixing, placing, joints, curing and testing - Reinforcement - Shuttering.

6 SPECIFICATION OF BRICKWORK, MASONRY AND WATERPROOFING

Brickwork: Bricks; Mortars; Brickwork; Damp-proof Courses; Faced Brickwork, etc.

Masonry: Dressed Stonework; Rubble Walling; Special Stonework; Fixings; Cast Stonework.

Waterproofing: Asphalt; Bitumen Sheeting.

\section{Specification of Piling}

Concrete Piles, including materials, shoes, casting, curing, trial piles, handling, pitching, driving and lengthening. Timber Piles, including timber, creosoting or tarring, shoes and rings, pitching, driving and cutting off heads. Steel Sheet Piling, including driving, cutting and drilling piles. 
8 SPECIFICATION OF IRON AND STEELWORK

Structural Steel - Fabrication - Erection - Bolting - Riveting -

Welding - Measurement - Testing - Ladders - Guardrails - Open

Steel Flooring - Painting - Wall and Roof Sheet Coverings: Asbestos

Cement; Aluminium; Corrugated Steel.

9 SPECIFICATION OF TIMBERWORK

Timberwork in Wharves and Jetties: Quality of Timber; Workmanship;

Fender Piles, Rubbing Pieces, Walings, Braces, Guardrails and Decking;

Tarring and Creosoting; Bolts and Nuts; Measurement; Equipment -

Steps, Footbridge and Scumboards - Joinery: Quality of Timber;

Windows; Doors; Miscellaneous Joinery Work; Painting.

10 Specification of Roads and Pavings

Materials - Road Bases, including lean concrete and soil cement -

Flexible Road Construction: Tarmacadam; Bitumen Macadam; Rolled

Asphalt; Cold Asphalt; Surface Dressing - Concrete Carriageway

Construction - Kerbs, Channels, etc. - Road Gullies - Electric Cable

Ducts - Footpaths: Tarmacadam; Asphalt; Flagged; 'Insitu' Concrete -

Grass Verges - Chain-link Fencing.

11 Specification of Sewers and Drains

Materials - Excavation - Pipelaying, including concrete protection and testing of pipes - Manholes: Brick and Precast Concrete; Associated Metalwork - Tunnel and Shaft linings: Cast Iron and Precast Concrete Segments; Jointing; Grouting; Concrete Lining - Ventilating Columns Sewage Works Filters, Scumboards and Screens.

\section{Specification of Pipelines}

Materials, including valves - Pipelaying under varying conditions -

Watercourse and River Crossings - Reinstatement of Trench Surfaces -

Testing and Sterilisation of Pipes - Valve Chambers: Sluice Valves;

Air Valves; Washouts; Hydrants.

\section{SPECification of Railway TrackWORK}

Preliminary Work - Track Materials: Ballast; Sleepers; Rails; Fishplates;

Rail Fixings; Separators; Bearing Plates; Chairs and Keys; Laying

Permanent Way: Laying Ballast; Laying Track; Points and Crossings;

Measurement of Railway Work.

Appendix I List of British Standard Codes of

Practice relating to Civil Engineering Work

Appendix II List of British Standards relating to

Civil Engineering Work

Appendix III Typical Programme of Works covering

Tunnels and Shafts to a Circulating Water System to a Power Station

Appendix IV Metric Conversion Table

Index 